\title{
TURKEY VULTURE BREEDING RECORDS IN SASKATCHEWAN
}

\section{by C. Stuart Houston, 863 University Drive, Saskatoon}

My own Turkey Vulture quest has drawn a blank for 26 consecutive vears - I have yet to see my first nest and have yet to band a vulture. I elieve the only vulture banded in Saskatchewan was one captured at Prud'homme and brought to A. McTherson in Saskatoon on August 10, 1951 (McPherson, 1952).

Other nest seekers have been more uccessful, with at least 12 nests on record for the province, a good numwer for a relatively uncommon though videly distributed species. It seems worthwhile to place them on record, ince several fill in the question mark ver central Saskatchewan in Godrey's ange map in Birds of Canada (1966).

1. Rush Lake, 1893. Two eggs on round, found by Walter Raine in May. Raine noted this species daily at Rush Lake in 1891 but did not find a pest that year. His Indian guide, John, old him that Turkey Vultures had been more numerous in his boyhood when buffalo were plentiful on the rairie. After a buffalo had been killed and the refuse left, two or three ultures would appear. Before many hours had elapsed their numbers would ncrease to 20 or 30 ; here they would ight over the carcass, and eat to such xcess and become so crammed that they were unable to fly. (Raine, 1892 nd Macoun, 1909).

2. Old Wives Creek, 1895. Found oreeding in May by John Macoun near Home's Ranch at the mouth of the creek (presumably Wood River at the western extremity of Old Wives Lake). (Macoun, 1909).

3. Moose Jaw, 1897. A set of two ggs taken near Moose Jaw, May 12, 1897 was in the Walter Raine collecion (Macoun, 1909).

4. Quill Lake, 1914. Nest with two foung birds under a large rock on the dge of the lake. H. C. Grose says "I am positive from the description that his is correct." (Grose, 1917).
5. Old Man on His Back Plateau, 1915. Two downy young with pinfeathers on ground in a thick clump of saskatoon bushes at the head of a small narrow side-coulee, protected by a steep bank on the west side. Found by R. D. Symons when on a branding roundup on south side of plateauabout 14 miles south and somewhat east of the present site of Robsart.

6. Beaver River, 1920. Nest with one young among deadfall logs on a jackpine sand ridge north of river near Barnes Crossing. It was found by Leland Bradford and described to R. D. Symons the following winter.

7. Murray Lake, 1933. Nest with two downy young in a slight hollow on top of the bank on an island at the east end of the lake. It was among several large round rocks with snowberry growing between and some saskatoon and poplar to the three sides not facing the lake. (Symons, 1967).

8. Touchwood Hills, about 1934. Nest with two young under a fallen $\log$ in thick growth of trees on island in lake about 14 miles north of Punnichy. (McKin, 1944 and 1945).

9. Madge Lake, 1942. An adult came out of a hollow log on the forest floor on an island in the lake. F. J. Hartley Fredeen, involved in limnological research at the time, presumed it was nesting but did not disturb it further.

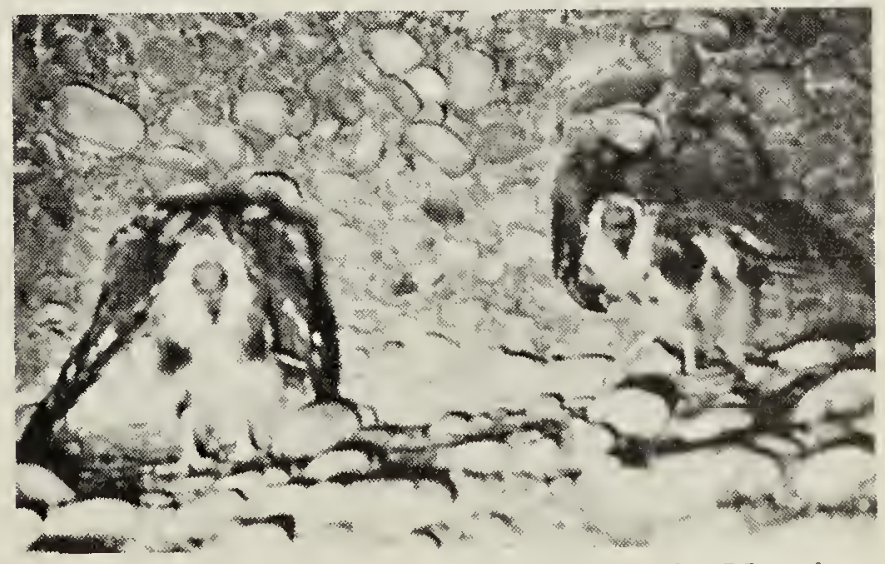

Photo by Lee and Lewis Morrison

Young Turkey Vultures in cave,

July, 1952 


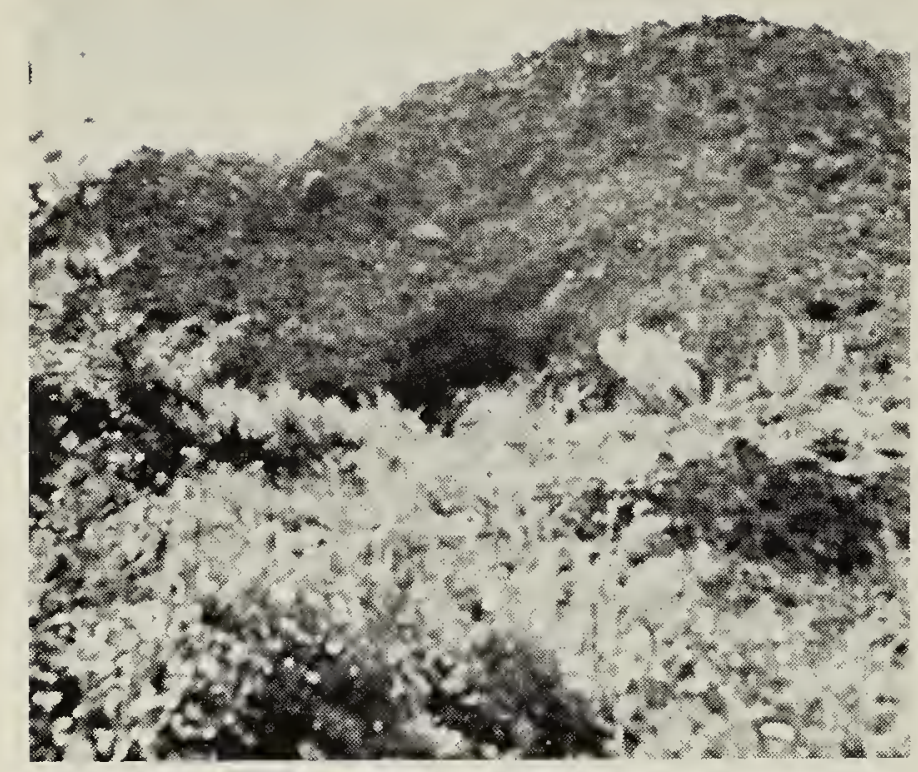

Photo by Lee and Lewis Morrison, Robsart

Conglomerate cave near Frenchman River, used as nest of Turkey

Vulture, July 1952.

10. Frenchman River, 1952. Nest with two young in a large cave of conglomerate rock on the west side of "Woody Coulee", at the extreme southeast corner of section 28, township 6 , range 24 , about four miles west of Ravenscrag. It was found in late July, perhaps July 23, by Lewis and Lee Morrison. They have kindly allowed their photographs to illustrate this article.

11. Moose Mountain Park, 1959. A nest with one egg was found on June 10,1959 , by a Museum party, including Fred Lahrman and Richard Fyfe who reported it to the Prairie Nest Records Scheme. It was on rotten wood under heavy brush on an island in Jabe Lake, where Great Blue Herons were nesting in the trees.

12. Near Big Beaver, 1965. Nest with two young in cave about three feet above the ground, seven miles south and seven miles east of Big Beaver and less than a mile north of the United States boundary. The large cave was 12 feet wide, 16 or 20 feet deep and up to five feet in height, with an entrance $4 \frac{1}{2}$ feet wide and $2 \frac{1}{2}$ feet high. The young were banded by Bernie Haysom on July 3, 1965.

H. H. Mitchell evidently knew of a bona fide breeding record since he noted this species as "found breeding in Qu'Appelle Valley" with no further details given. Possible nesting records for the South Saskatchewan River include a young bird found in the hills near Demaine in September 1961 which may have been raised in the area as its wing appeared to have been injured when still a fledgling (Santy, 1962). Richard Fyfe observed a pair along Swift Current Creek just south of the river on May 23 and June 21,1968 , with an adult flying from a large hole in the cliff on the first occasion.

Other sightings of this species throughout the nesting season are known from many localities in the province, chiefly the sparsely settled areas. Only a few of these that illustrate their declining numbers will be mentioned here. George H. Lang of Indian Head reported to the U.S. Biological Survey that he had seen only one in 1904, on June 20, and one in 1913, on April 28, whereas formerly they had been very common and bred locally. Laurence B. Potter of Eastend reported in 1930 that the Turkey Vulture, once plentiful in that area, became uncommon as grain farming largely displaced cattle ranching. They ceased to be regular residents at Good Spirit Lake northwest of Yorkton in 1896, but persisted in good numbers at Round and Crooked Lakes in the Qu'Appelle Valley until the early 1940's and as many as 30 could be seen soaring over Madge Lake as late as 1945 (Houston, 1949).

I wish to thank the many people mentioned whose observations have made the above report possible. My gratitude would know no bounds if someone could find another nest this year and phone me collect at Saskatoon 244-0742.

\section{LITERATURE CITED}

Godfrey, W. E. 1966. The birds of Canada. Nat. Mus. of Can. Bull. No. 203, Ottawa.

Grose, H. C. 1917. Report on birds in: Annual report of the Saskatchewan Naturalists' Club 1916. Report on the Chief Game Guardian, Regina.

Houston, C. Stuart. 1949. The birds of the Yorkton District, Saskatchewan. Canadian Field-Naturalist $63: 215-241$.

McKim, L. T. 1944. Bird notes. Blue Jay $2: 30$. -1945. Memories of a naturalist. Blue Jay $3: 22-23$. 
cPherson, A. 1952. Burrowing Owls. Blue Jay $10: 3$.

acoun, John, and James M. 1909. Catalogue of Canadian birds. Government Printing Bureau, Ottawa.

itchell, Hedley H. 1924. Birds of Saskatchewan. Canadian Field-Naturalist 38:101-118. aine, Walter. 1892. Bird-nesting in NorthWest Canada. Hunter, Rose \& Co., Toronto. anty, Dave. 1962. Apparent breeding record of Turkey Vulture along South Saskatchewan River. Blue Jay $20: 14$.

ymons, R. D. 1967. Hours and the birds. University of Toronto Press, Toronto.

\section{BROWN THRASHER AT ISLAND LAKE, MANITOBA}

by A. E. Wilson, Island Lake

A Brown Thrasher found by 12ear-old Norman Wood is a new pecies record for Island Lake, Maniba. The bird was found almost dead rom cold under a boat on November 1, 1968. The bird undoubtedly was straggler and not a local resident, $r$ its breeding range lies far to the outh. Godfrey (1966. The birds of anada) gives Dauphin as a northern reeding locality in Manitoba. Incientally, this is a species unfamiliar the boy's father who is a life-long sident of Island Lake.

R. W. Nero informs me that J. R. ehl, Jr. and Mrs. I Smith list the rown Thrasher in their coming reised account of the birds of Churchill icinity, far to the north of Island ake. Its occurrence at both places lust be regarded as accidental.

The date of its occurrence is late $r$ this species in any case. Bent 1948. Life histories of North Amerian nuthatches, wrens, thrashers and heir allies) mentions dates in Sepember and early October as late eparture dates for Canadian localies; November 13 is the latest date iven for Washington, D.C. The pecimen will be given to the Maniba Museum of Man \& Nature in Vinnipeg.

Editor's Note: Because la'te fall eparture dates are unusual for the rown Thrasher, it is worth menoning here that $\mathrm{Al}$ and Betty Binnie ecorded a Brown Trasher seen at legina as late as December. 21, 1968.]

\section{OWL AND HAWK NESTS}

Anyone finding an active nest of any bird of prey in Saskatchewan, is asked to contact Dr. Stuart Houston, 863 University Drive, Saskatoon, who will notify the nearest bander. Nests within 50 miles of Saskatoon, Regina, Indian Head or Yorkton will be visited and the young banded; nests at a greater distance may be visited, including most of those within 100 miles of Saskatoon, depending on numbers, and time available. With the declining numbers of many birds of prey, including now the Marsh Hawk, it is important to learn all we can of nesting success and migration routes. Experience has shown that banding visits do not adversely affect nesting success, but have contributed greatly to our knowledge.

\section{PRAIRIE NEST RECORDS SCHEME}

Contributors are reminded to send 1969 nest record cards to Dr. Robert W. Nero, Prairie Nest Records Scheme, Manitoba Museum of Man and Nature, Winnipeg 2. If you have not previously contributed to the scheme but are interested in keeping records, write to $\mathrm{Dr}$. Nero for information and nest record cards. Also available from him is the summary of the scheme's first 10 years operation (1958-67).

\section{GREAT GRAY OWL CONCENTRATION}

Great Gray Owls appeared unexpectedly in southeastern Manitoba in late October and early November, 1968. They have since been seen in a number of localities in an area of about 45 miles by 75 miles extent bordering the west side of the Whiteshell Provincial Park east of Winnipeg. Largest numbers have been seen near extensive stands of lowland black spruce, but they have been sighted in a variety of habitats and 